\title{
Macroinvertebrate assemblages and biodiversity levels: ecological role of constructed wetlands and artificial ponds in a natural park
}

\author{
Laura SARTORI, ${ }^{*}$ Sergio CANOBBIO, Riccardo CABRINI, Riccardo FORNAROLI, Valeria MEZZANOTTE \\ Dipartimento di Scienze dell'Ambiente e del Territorio e di Scienze della Terra (DISAT), Università di Milano Bicocca, Piazza della \\ Scienza 1, 20126 Milano, Italy \\ *Corresponding author: laura.sartori@unimib.it
}

\begin{abstract}
Constructed wetlands play an important role in water supply, floodwater retention and nutrient removal, at the same time allowing the restoration of lost habitat and the preservation of biodiversity. There is little knowledge about the biodiversity that can be found in these artificial environments along time, especially at the invertebrate community level. Macroinvertebrate assemblages, water chemistry, morphology, and environmental characteristics of natural ponds, artificial pools and constructed wetlands in Parco Pineta (Northern Italy) were studied to evaluate the effects of local factors on macroinvertebrate communities. The objective was to verify if each ecosystem could equally contribute to local biodiversity, regardless of its natural or artificial origin. Principal Components Analysis showed that ponds were divided into clusters, based on their morphology and their water quality, independently from their origin. The composition of macroinvertebrate communities was similar among natural wetlands and ponds artificially created to provide new habitats in the park, while it was different among natural wetlands and constructed wetlands created for wastewater treatment purposes. Biodiversity of natural ponds and constructed wetlands, evaluated using taxa richness, Shannon index, and Pielou index, was comparable. Canonical Correspondence Analysis highlighted differences in macroinvertebrate community composition and pointed out the relationships among macroinvertebrates and various environmental variables: habitat heterogeneity resulted as the most relevant factor that influences taxa richness. Water quality also affects the macroinvertebrate community structure. We determined that constructed wetlands with higher pollutant concentrations show different assemblage compositions but comparable overall macroinvertebrate biodiversity. Constructed wetlands became valuable ecological elements in the area almost immediately, due to fast colonizing invertebrates. However, we also assume that differences in macroinvertebrate assemblage compositions among wetlands with different origins lead to differences in the functionality of each ecosystem.
\end{abstract}

Key words: Freshwater macroinvertebrates, habitat heterogeneity, macroinvertebrate community composition, natural wetlands, constructed wetlands, taxonomic diversity.

Received: May 2014. Accepted: November 2014.

\section{INTRODUCTION}

Artificial ponds are often created for purposes such as water supply, floodwater retention, recreation, education, or wildlife management and research (Oertli et al., 2005). They can also be useful in wastewater treatments or can serve as elements of the local ecological network, substituting for natural wetlands. The recognition of the ecological services provided by wetlands has stimulated renewed efforts to protect, manage and construct them (Mitsch et al., 1998; Zedler, 2006), although their real contribute in enhancing biodiversity is still not clear. Some studies proved that created wetland systems can make net contributions to overall biodiversity, so they are often used in restoration projects to increase biodiversity in degraded river ecosystems (Palmer et al., 2007, 2010). On the other hand, some studies showed that in many restored wetlands ecosystem services may not be completely recovered even when wetlands appear to be biologically restored (MorenoMateos et al., 2012). Unless the man-made ecosystems are developed in a long-term perspective, they will be a sink for generalist fauna and cannot immediately replace wetland original faunas (Ruhí et al., 2013). There is also little knowledge on the processes taking place in these artificial environments and on their ecological function, especially at the invertebrate community level (Herrmann et al., 2000; Ruhí et al., 2009). Research on constructed wetlands has most frequently been addressed to evaluate their efficacy in pollution removal and flood mitigation, with less attention to their role as ecosystems (Mitsch et al., 1998; Spieles et al., 2006). Only a few studies (Spieles and Mitsch, 2000; Fairchild et al., 2000; Balcombe et al., 2005; Becerra-Jurado et al., 2009; Gallardo et al., 2012) have analysed the macroinvertebrate communities of constructed wetlands and the environmental factors that influence them. A deeper knowledge of the biodiversity hosted in these environments is needed to determine if artificially created ponds and constructed wetlands are also appropriate restoration tools for biological conservation (Ruhí et al., 2009). It is also relevant to analyse the effectiveness of wetlands to mitigate the 
habitat loss at a local scale (Gallardo et al., 2012). Macroinvertebrates are directly affected by the physical and chemical integrity of the surrounding environment, including water quality (EPA, 2002). They are known to influence the rates of nutrient cycling and decomposition, to have a central position in the wetland food webs and to integrate environmental impacts and changes through time (Scatolini and Zedler, 1996; Sharitz and Batzer, 1999; Brady et al., 2002; Stanczak and Keiper, 2004). Therefore, they are potentially useful as indicators of restoration success (Campbell et al., 2002).

We examined the macroinvertebrate communities and their relationships with water quality and habitat heterogeneity in eight ponds within a natural park in northern Italy. We chose four artificial ponds created for various purposes and four natural ecosystems that served as reference sites. The artificial and constructed wetlands were expected to act as a refuge for aquatic organisms in areas where water resources were scarce, making a net contribution in the local ecological network. The general aim of the work was to improve the understanding of factors affecting the invertebrate community structure in artificial ponds and constructed wetlands. In particular, we intended i) to assess the role of the artificial wetlands in improving biodiversity and ii) to compare the macroinvertebrate community composi- tion and biodiversity observable in artificial ecosystems with those of natural wetlands. Our hypothesis is that macroinvertebrate communities in constructed wetlands that have a habitat availability comparable to that of natural wetlands can rapidly reach the same levels of biodiversity. Evidence about the successful inclusion of constructed wetlands of various kind in ecological networks can have implications in local biodiversity management and in artificial wetland design.

\section{METHODS}

\section{Sampling sites}

Eight wetlands were selected within Parco Pineta, a natural park in Northern Italy, $35 \mathrm{~km}$ northwest of Milan (Fig. 1). They lie in a hilly wooded and cropped area, consisting of clay terraces originating from Pleistocene erosion, which allow water accumulations. The entire park, enclosed by an urbanized area, is located in the wider territorial area of the Alps piedmont hills and covers about $4860 \mathrm{ha}$. On average, the maximum summer temperatures (July) are approximately $22.0^{\circ} \mathrm{C}$ and the minimum winter temperatures (January) are $1.6^{\circ} \mathrm{C}$; annual temperature variation is around $20.3^{\circ} \mathrm{C}$. The total rainfall is about $1400-1500 \mathrm{~mm}$ per year, with a primary maximum in
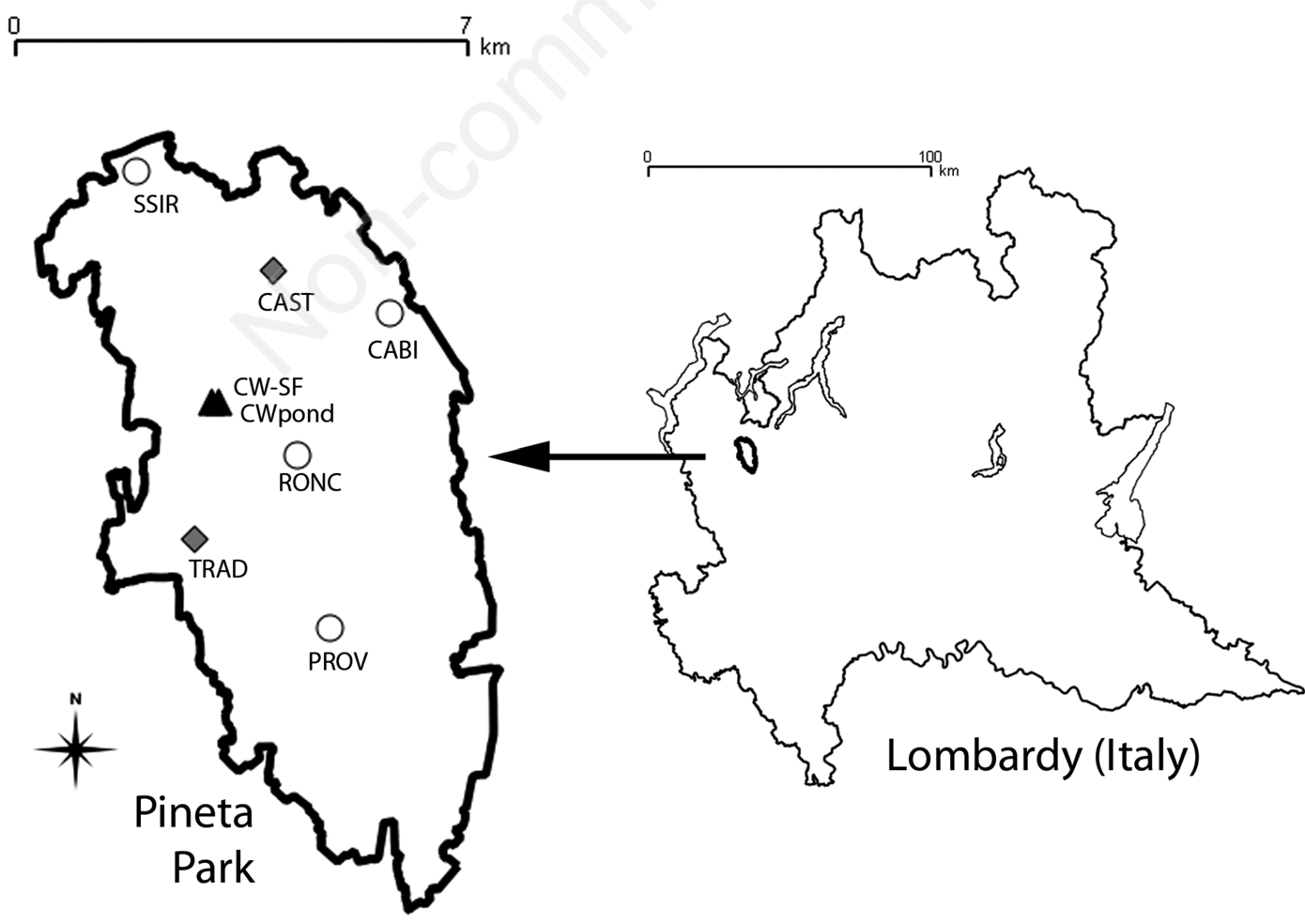

Fig. 1. Study area with the location of the eight considered wetlands. White dots, natural ponds; black triangles, constructed wetlands; grey diamonds, artificial pools. 
spring and a secondary in autumn. The climate can be defined as mildly continental.

The wetlands were selected for this study on the basis of their origin, microhabitats, bank morphology and depth. Natural (NAT) wetlands were characterized as erosional features or by-products of anthropogenic activities carried out in the past centuries. These wetlands had multiple microhabitats, variable depths (maximum depth $>1 \mathrm{~m}$ ) changing gradually and typical wetland vegetation (different macrophytes and riparian grasses). The four studied NAT ponds are designated as: Cà Bianca (CABI), San Siro (SSIR), Proverbio (PROV), Roncamocc (RONC). Artificial Park pools (PARK) have been made by the Park management with the primary purpose of providing habitat and recovery for amphibian species. They are oval-shaped, $50 \mathrm{~m}^{2}$ surface and $1 \mathrm{~m}$ deep. The considered PARK pools are two, Tradate (TRAD) and Castelnuovo Bozzente (CAST). The two constructed wetlands $(\mathrm{CW})$ receive wastewater from the mixed sewer system of a hamlet placed in a wooded area, and include a surface flow pool (CW-SF) and a following smaller pond (CW-pond). They cover 306 and 105 $\mathrm{m}^{2}$, respectively, and both have a maximum depth of 0.6 $\mathrm{m}$. Although both man-made, we decided to consider separately PARK pools and CW because of their different scope and their extremely dissimilar water nutrient concentrations which were much higher in $\mathrm{CW}$ pools than in PARK wetlands.

\section{Habitat characteristics}

Environmental characteristics were measured in each pond to describe the whole ecosystem. Particularly, we documented areal coverage of submergent, emergent and floating macrophytes, calculated as the percent coverage of the whole wetland area. For the riparian grasses the degree of coverage was calculated as the percent area covered within a riparian $1 \mathrm{~m}$ buffer. We also evaluated the presence/absence of wood structures such as floating and submerged trunks, roots and living trees.

Gradual bank slopes, bends in the pond perimeter, variable depths, and permanent shady or sunny areas given by the canopy coverage were considered in terms of presence/absence to account for the morphological habitat diversity. A score between 0 and 6 was calculated by the sum of the presences of such elements. The morphological diversity was low if the score was in the 0-3 range and high if it was in the 4-6 range (Tab. 1). A similar approach to determine habitat heterogeneity had been used by Martínez-Sanz (2012). Tab. 1 also reports the total number of microhabitats in each pond considering both macrophyte coverage and morphological characteristics.

\section{Water quality}

Physico-chemical and microbiological parameters (Tab. 2) were analysed in samples collected at the same time as macroinvertebrate qualitative samples. Some water parameters (temperature, dissolved oxygen, oxygen saturation and electric conductivity) were measured in situ, using a Hach-Lange probe with a LDO oxygen sensor. For the other parameters $[\mathrm{pH}$, total chemical oxygen demand (COD), total phosphorus, total nitrogen, ammo-

Tab. 1. Environmental variables and morphological differentiation in each pond. The coverage of macrophytes was calculated as percentage of the whole pond area; the coverage of riparian grasses was calculated as the occupied percentage of a riparian $1 \mathrm{~m}$ buffer. Morphological differentiation has been counted as sum of morphological characteristics presence (low if the result of the sum was 0-3; high if the result of the sum was 4-6). The total number of microhabitats includes both macrophyte coverage and morphological characteristics.

\begin{tabular}{|c|c|c|c|c|c|c|c|c|c|}
\hline & & \multicolumn{2}{|c|}{ CW } & \multicolumn{2}{|c|}{ PARK } & \multicolumn{4}{|c|}{ NAT } \\
\hline & & CW-SF & CW pond & CAST & TRAD & CABI & PROV & RONC & SSIR \\
\hline \multirow{5}{*}{$\begin{array}{l}\text { Macrophyte } \\
\text { coverage }\end{array}$} & Submergent macrophytes & $0 \%$ & $0 \%$ & $50 \%$ & $70 \%$ & $0 \%$ & $30 \%$ & $0 \%$ & $30 \%$ \\
\hline & Emergent macrophytes & $60 \%$ & $10 \%$ & $30 \%$ & $30 \%$ & $20 \%$ & $20 \%$ & $70 \%$ & $40 \%$ \\
\hline & Floating macrophytes & $40 \%$ & $90 \%$ & $20 \%$ & $0 \%$ & $30 \%$ & $30 \%$ & $0 \%$ & $10 \%$ \\
\hline & Free water & $0 \%$ & $0 \%$ & $0 \%$ & $0 \%$ & $50 \%$ & $20 \%$ & $30 \%$ & $20 \%$ \\
\hline & Riparian grass & $0 \%$ & $10 \%$ & $40 \%$ & $40 \%$ & $20 \%$ & $10 \%$ & $50 \%$ & $30 \%$ \\
\hline \multirow{8}{*}{$\begin{array}{l}\text { Morphological } \\
\text { characteristics }\end{array}$} & Woody structures & no & no & no & no & yes & yes & yes & yes \\
\hline & Gradual bank slopes & no & yes & yes & yes & no & yes & yes & yes \\
\hline & Bends & no & no & no & no & no & yes & no & yes \\
\hline & Variable depth & no & yes & no & no & yes & yes & yes & yes \\
\hline & Permanent shady areas & no & yes & no & yes & no & yes & no & yes \\
\hline & Permanent sunny areas & yes & yes & no & no & yes & no & no & no \\
\hline & Morphological differentiation & low & high & low & low & low & high & low & high \\
\hline & Total number of microhabitats & 3 & 7 & 5 & 5 & 7 & 10 & 6 & 10 \\
\hline
\end{tabular}

CW, constructed wetlands; PARK, artificial pools; NAT, natural ponds; CAST, Castelnuovo Bozzente; TRAD, Tradate; CABI, Cà Bianca; PROV, Proverbio; RONC, Roncamocc; SSIR, San Siro. 
nia nitrogen, Escherichia coli], water samples were collected in bottles, kept in the dark in refrigerated bags, and analysed in laboratory within $24 \mathrm{~h}$ of collection, according to Standard Methods (APHA, 1998).

\section{Biological samplings}

Macroinvertebrates were collected between June 2008 and August 2009 by qualitative seasonal samplings. Samples were taken with a $500 \mu \mathrm{m}$ mesh size net $\left(0.05 \mathrm{~m}^{2}\right)$ in each pond, according to Gascón et al. (2008), from all microhabitats at each site, considering the present vegetation species (submergent, emergent and floating macrophytes; riparian grass), the bottom characteristics, the solar exposition, the banks morphology and the presence of wood structures.

Samples were preserved in $90 \%$ ethanol before being sorted, counted, identified at the lowest taxonomical level possible (usually species or genus; family for Diptera and Oligochaeta) and then conserved in 4\% formaldehyde. Taxa richness, Shannon index and Pielou index were evaluated using data at family level to compare all macroinvertebrates at a homogeneous taxonomical level.

\section{Data analysis}

Principal components analysis (PCA) was performed to evaluate the relationships of all environmental and water quality variables.

Analysis of similarity (ANOSIM; 999 permutations, Bray-Curtis as a distance measure) was performed to assess any significant difference among community assemblages. Similarity Percentage (SIMPER) analysis was used to determine which macroinvertebrate families explained more dissimilarity among the three wetland categories (NAT, PARK, and CW). The identification of such families was based on the ratio average dissimilarity values/standard deviation: taxa having the ratio value $>1$ were considered to discriminate wetland categories, as reported in Ruhí et al. (2013).

A one-way analysis of variance (ANOVA) was used to evaluate any significant difference among biodiversity metrics in the three wetland categories. Thus, we considered the wetland categories as predictor variables (treatments) and three biodiversity indices (taxa richness, Shannon index and Pielou index) as response variables. A posteriori pairwise comparisons between treatments were carried out using Tukey's HSD test. ANOSIM and SIMPER analyses were conducted using the vegan package version 2.0-10 (Oksanen et al., 2013) in R Project software (R Core Team, 2013); ANOVA and Tukey's HSD test have been carried out using the software XLSTAT 7.

A Canonical Correspondence Analysis (CCA) was performed to evaluate the relationships between macroinvertebrate communities and site environmental character-

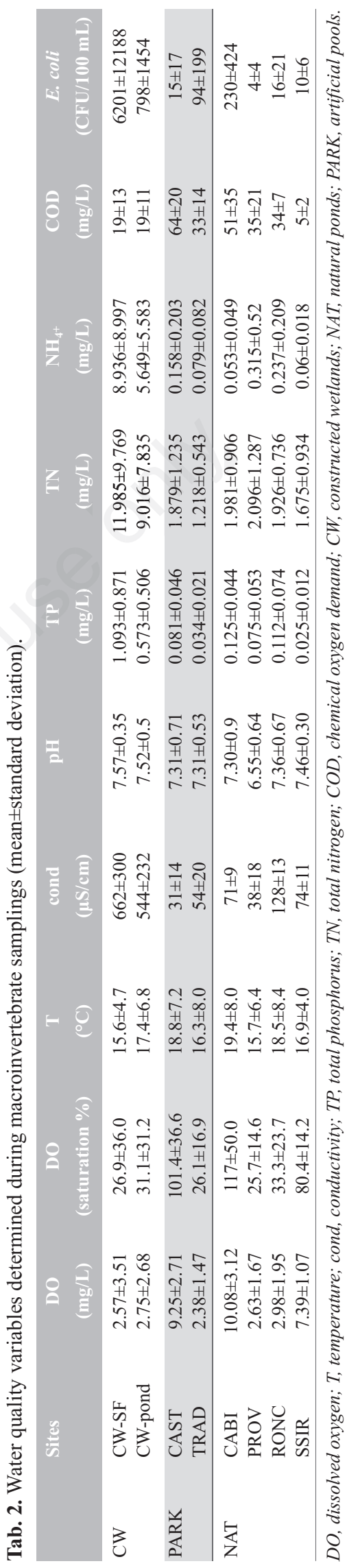


istics using the software CANOCO 4.5 (ter Braak and Smilauer, 1998). A preliminary Detrended Correspondence Analysis (DCA), performed on the invertebrate community data, showed a gradient length $>3 \mathrm{SD}$, indicating a unimodal response and, thus, justifying the use of CCA. Only the environmental variables significantly related (Monte Carlo permutation test, $\mathrm{P}<0.05$ ) to macroinvertebrate distribution were retained. Variables showing strong multicollinearity (Variance Inflation Factors $>20$ ) were also excluded from the analysis (see Results section).

\section{RESULTS}

\section{Environmental characteristics of the ecosystems}

The morphological diversity of ponds is shown in Tab. 1. SSIR and PROV resulted to have the highest values for morphological microhabitat differentiation and macrophyte coverage, thus allowing the highest total number of microhabitats, while CW-SF was the least differentiated for morphology and vegetation. Even if CAST and CABI had a low level of morphological differentiation, they were characterized by the presence of various microhabitats due to the macrophyte richness or to the presence of wood structures. CW-pond also presented high morphological differentiation associated to vegetation diversity. Water quality analyses showed that CW-pond and CWSF had higher concentrations of total phosphorus, total nitrogen and ammonia nitrogen than natural (NAT) and artificial (PARK) ponds, as well as higher conductivity and $E$. coli counts. They were also characterized by low dissolved oxygen (DO) concentrations, as were RONC and PROV natural ponds, where the decomposition of massive vegetation was particularly intense. All the other natural and artificial ponds presented more similar water quality; the DO oversaturation in CABI and in CAST, more exposed to sunlight than the other ponds, was due to relevant phytoplankton blooms, influencing also the total COD value (Tab. 2).

In the PCA analysis of environmental and water quality variables, the emergent macrophytes variable was excluded because of its ubiquity in each considered ecosystem. As shown in Fig. 2, the $66.13 \%$ of variance was explained by the first two PCA axes together. Morphological ecosystem diversity showed a significant positive relationship with the total available microhabitat number (bilateral $t$-test; $\alpha=0.05$ ). No significant relationship was found between morphological characteristics and water quality, with the exception of riparian grass and temperature. However, temperature is related to sunlight exposition rather than to water quality. The whole set of water quality parameters was covariant. On axis $1 \mathrm{CW}$ pond and CW-SF appeared to be clustered and separated from the other ponds, because of their water quality. On the other hand, a correlation could be observed between them and the other ponds on axis 2 , that showed a gradient in microhabitats differentiation, in which CW-pond and CW-SF have an intermediate position. The two PCA axes showed that ponds and pools were divided into three clusters, based on their relationships with higher morphological diversity (PROV and SSIR), nutrient concentrations (CW-pond and CW-SF) and phytoplankton blooms, related to COD and high DO concentrations (CABI and CAST mainly). So, the water quality gradient was confirmed to be relevant and to be likely to affect the macroinvertebrate community assemblages.

\section{Macroinvertebrate communities}

A total of 35 macroinvertebrate taxa (at family level) were collected from the whole pond set. In order to compare NAT, PARK and CW, the mean percent abundance for each macroinvertebrate class (subclass for Clitellata) were calculated (Fig. 3). CW and PARK showed a similar

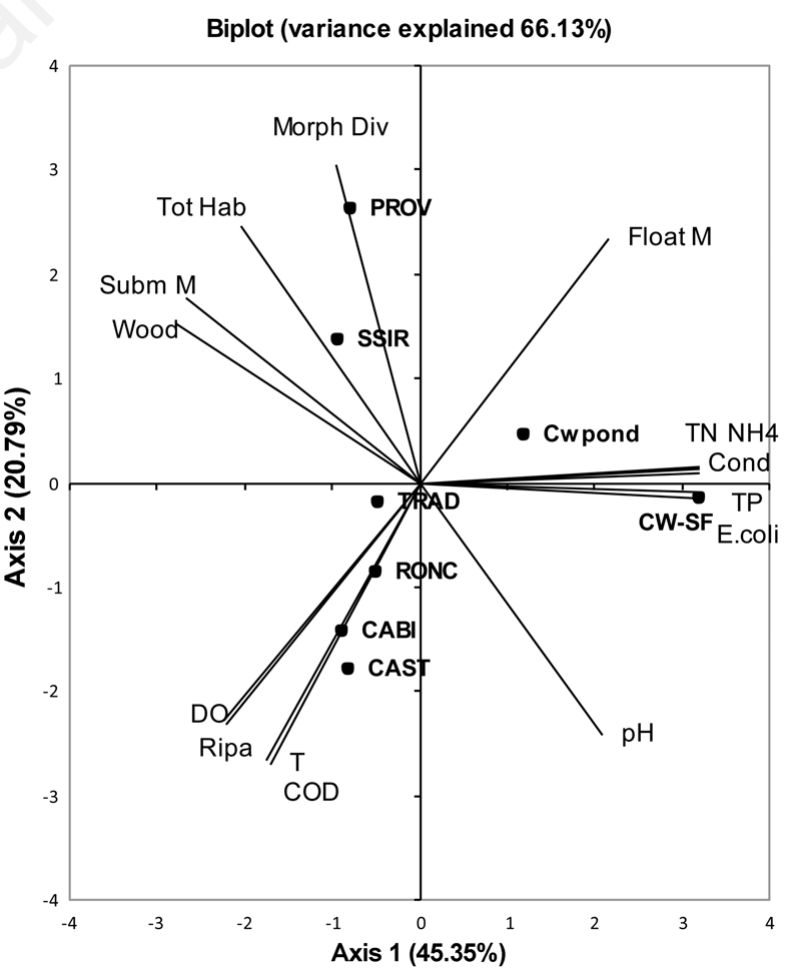

Fig. 2. PCA biplot diagram showing relationships (first two axes, $66.13 \%$ of the total variance) between some of the environmental variables (lines) and sites (dots). Morph Div, morphological diversity; Tot Hab, number of total microhabitats; Subm M, submergent macrophytes; Float M, floating macrophytes; Wood, woody structures; Ripa, riparian grass; CAST, Castelnuovo Bozzente; TRAD, Tradate; CABI, Cà Bianca; PROV, Proverbio; RONC, Roncamocc; SSIR, San Siro. 
percent composition; ( $>90 \%$ Insecta Gastropoda and Oligochaeta for the remaining fraction), while the NAT category displayed a higher level of diversity. Insecta turned out to be the most relevant class in the three ecosystem groups, although there were differences among the composition in the macroinvertebrate orders (Fig. 3). ANOSIM was used to compare the variation in community abundance and composition among the three wetland categories. The model resulted not significant $(\mathrm{R}=0.144$, $\mathrm{P}=0.073$ ), thus showing no significant difference in taxonomical composition among the three wetland categories.

SIMPER analysis was chosen to identify the taxonomical group which explained more dissimilarity among the three wetland categories (Fig. 4). A significant dissimilarity in taxa composition was observed between $\mathrm{CW}$ and NAT wetlands $(\mathrm{R}=0.318, \mathrm{P}=0.002)$ and was mainly driven by Chironomidae, Baetidae, Dytiscidae and Aeshnidae families. The dissimilarity between $\mathrm{CW}$ and PARK and between PARK and NAT was not significant.

For every pond biodiversity indices (Taxa richness, Shannon Index and Pielou Index) were calculated for each sampling campaign: Tab. 3 reports the indices mean val- ues for NAT, CW and PARK ecosystem categories. The values of the biodiversity indices for the three ecosystem categories were comparable, but slightly higher for the PARK group. In the ANOVA model evaluating the differences among the biodiversity indices there was no significant variation $(\alpha=0.05)$ among and within the three groups of sites and the null hypothesis (no treatment effect) had to be considered true (Tab. 3). Tukey's HSD test for pairwise comparison showed the absence of significant differences among the three treatments for all the biodiversity indices $(\alpha=0.05)$. This result agrees with ANOSIM response and confirms that no significant difference was observable in terms of biodiversity among the different wetland types, even though the taxonomical composition of the macroinvertebrate communities presented some differences.

\section{Relationship between environmental and biological characteristics}

The first two axes of the CCA exploring the relationship between macroinvertebrate taxa and environmental factors

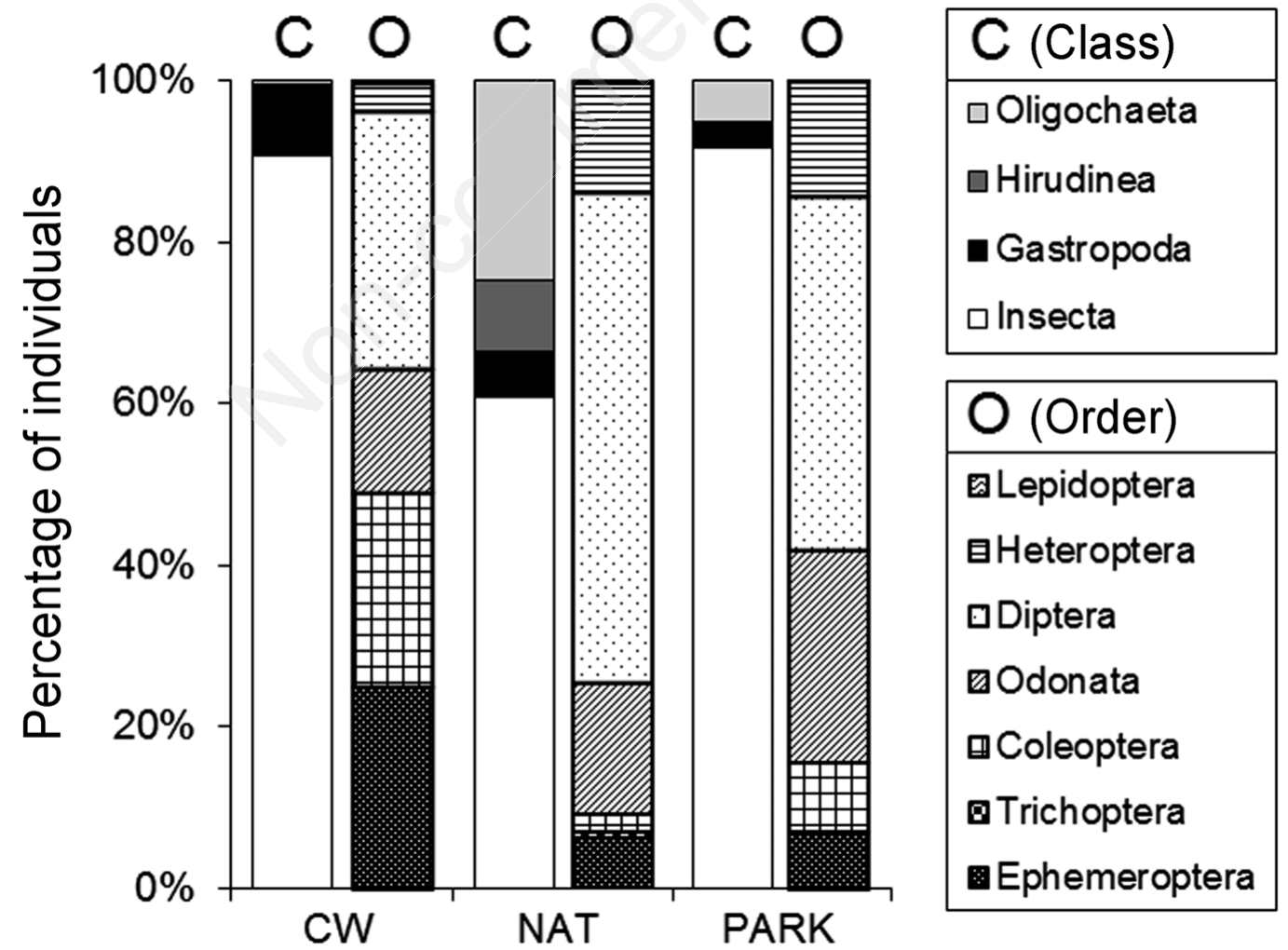

Fig. 3. Histograms representing the mean percentage of macroinvertebrate individuals belonging to different classes and Clitellata subclasses (histograms with $\mathrm{C}$ label) and the mean percentages of Insecta class composition (orders or suborders, histograms with $\mathrm{O}$ label) in each ecosystem category. CW, constructed wetlands; NAT, natural ponds, PARK, artificial pools. 
had eigenvalues of 0.473 and 0.300 , together explaining $59.9 \%$ of the total variation in the data set (Tab. 4). The Monte Carlo permutation test showed a significant result for the sum of all eigenvalues (499 permutations, $\mathrm{P}<0.05$ ). In the preliminary CCA analysis, seven environmental variables (conductivity, total phosphorus, emergent macrophytes, wood presence, morphology, fish presence and droughts) had high variance inflation factors (IF $>20)$, i.e., were highly correlated with other variables and were thus less significant in explaining the community assemblages, so they were excluded from the final CCA analysis (see methods). The environmental variables included in the final analysis were: surface area of the water body, DO, temperature, $\mathrm{pH}$, total nitrogen, ammonia nitrogen, COD, E. coli,

Tab. 3. One-way ANOVA table showing the sum of squares (SS), mean square (MS), the F-ratio and the P-value calculated for each biodiversity index.

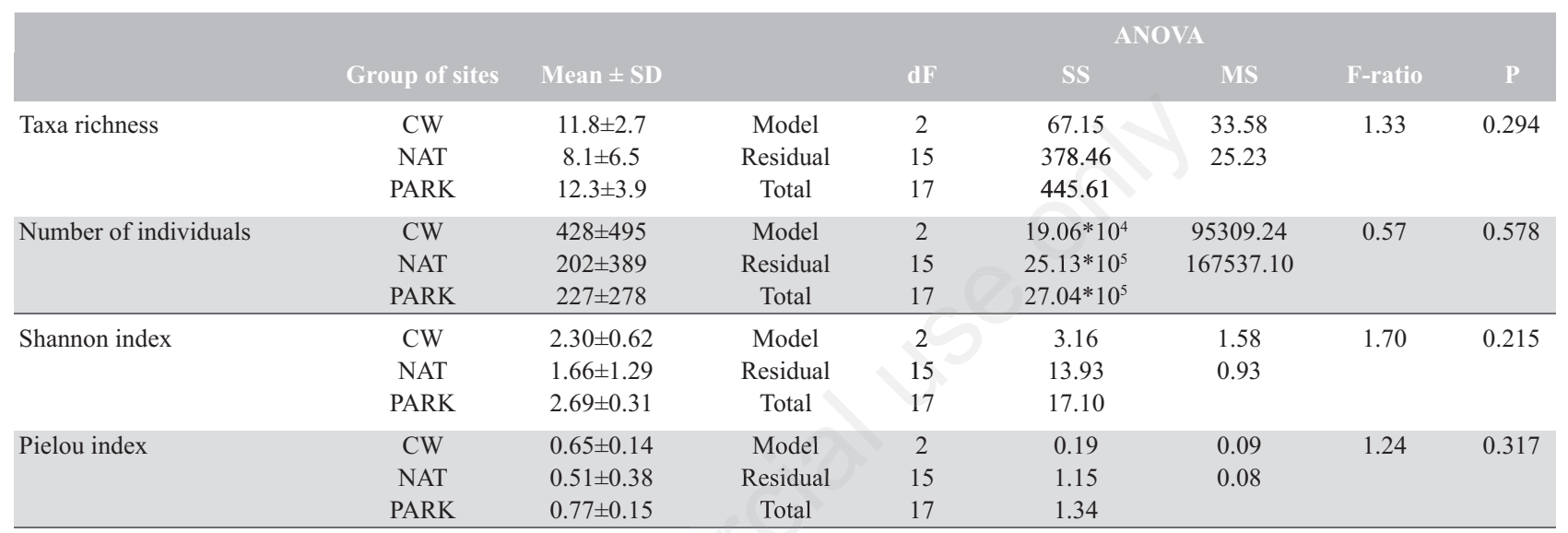

SS, sum of squares; MS, mean square; CW, constructed wetlands; NAT, natural ponds, PARK, artificial pools. P-value standard alpha level=0.05.

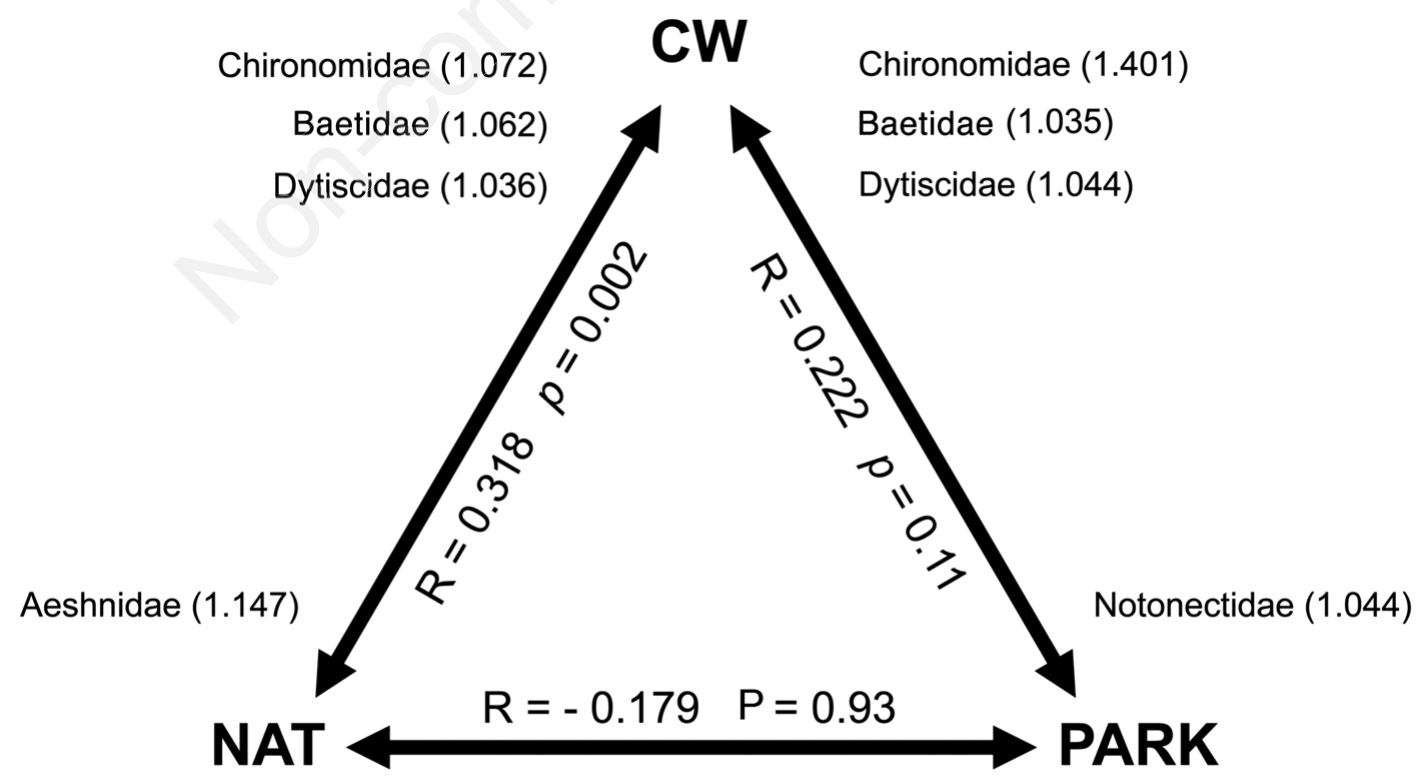

Chironomidae (1.173)

Fig. 4. Similarity percentage (SIMPER) analysis, revealing families that contributed most to dissimilarity between wetland categories (CW, constructed wetlands; NAT, natural ponds, PARK, artificial pools). The ratio (average dissimilarity values/standard deviation) is given in parenthesis. ANOSIM pairwise tests between wetland categories are also shown. 
floating macrophytes and riparian grass. It is worth remembering that, in the examined cases, COD was mostly related to the algal blooms rather than to the input of organic load. This is confirmed by the positive relationship between COD and DO (due to supersaturation caused by photosynthesis) and by the higher COD found in NAT and PARK ponds rather than in $\mathrm{CW}$, fed on domestic sewage.

Although the three ecosystem categories did not present significant differences in the overall biodiversity level, as shown by ANOSIM and ANOVA, differences in the community assemblages among the three categories were demonstrated by the CCA. The triplot diagram (Fig. 5) shows the distribution of the relative abundance of macroinvertebrates (with Insecta represented at order level) in the sampling sites. CWs appeared clustered because of their different water quality, which seemed to be preferred by Coleoptera, Ephemeroptera and Gastropoda, whose relative frequency is higher in constructed wetland samples. The other macroinvertebrate orders were probably limited by water quality and were related to elements unavailable in the CWs, such as the presence of diversified macrophyte communities (in PARK ponds and some of the NAT wetlands) or the larger surface area (mainly in NAT ponds) providing numerous microhabitats. The available habitats can allow the presence of different taxa, such as

Tab. 4. Summary of the canonical correspondence analysis. Monte Carlo test run for the sum of all eigenvalues was significant (499 permutations, $\mathrm{P}<0.05$ ).

\begin{tabular}{lccc} 
Axis & 1 & 2 & Total inertia \\
Eigenvalue & 0.473 & 0.300 & 1.585 \\
Species-environment correlations & 0.989 & 0.978 & \\
\hline $\begin{array}{l}\text { Cumulative percentage variance } \\
\quad\end{array}$ & 29.9 & 48.8 & \\
$\begin{array}{l}\text { of species data } \\
\text { of species-environmental relation }\end{array}$ & 36.7 & 59.9 & \\
Sum of all canonical eigenvalues & & & 1.290 \\
\hline
\end{tabular}

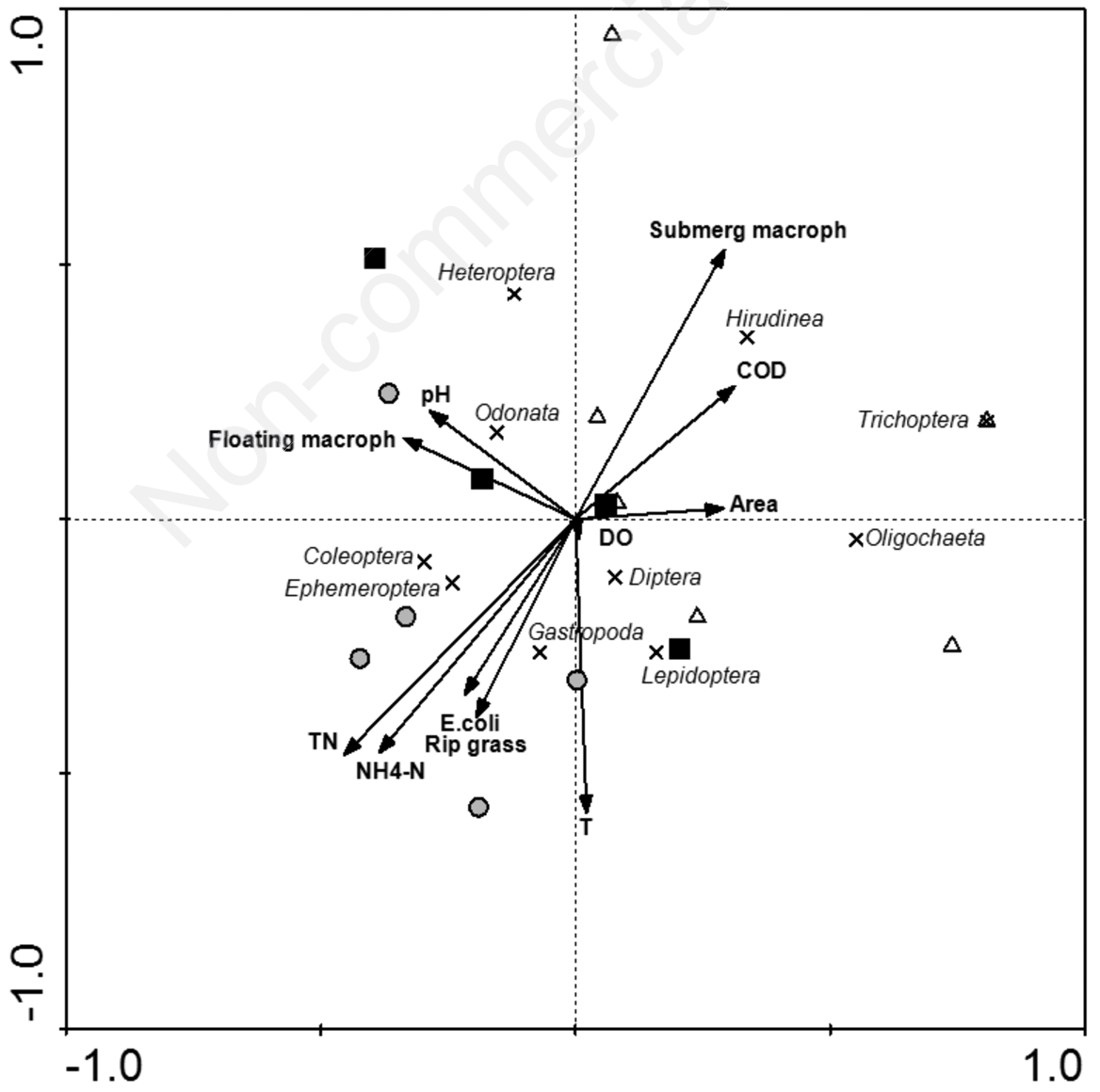

Fig. 5. CCA triplot diagram showing the relationships between macroinvertebrates (classes, orders or suborders), environmental variables and sampling sites. Triangles, natural wetlands; black squares, artificial wetlands; grey dots, constructed wetlands. 
Odonata, Hemiptera and Trichoptera. In this study, they appear more frequently in NAT and PARK ponds, notwithstanding the overall biodiversity and evenness of their communities is comparable to the one of CWs.

\section{DISCUSSION}

Differences in macroinvertebrate assemblages were observed among sites and were related to the different environmental, morphological and water quality conditions. Water chemistry and trophic conditions have often been cited as relevant factors affecting the macroinvertebrate community assemblage and biomass in lentic ecosystems (Friday, 1987; Rasmussen, 1988; Brodersen et al., 1998; Boix et al., 2008). Water body size and habitat structure also seemed to influence the macroinvertebrate communities differing in abundance and species composition (Oertli, 1995; Tolonen et al., 2001; Weatherhead and James, 2001; Della Bella et al., 2005). As suggested by Hansson et al. (2005), wetlands characterised by relatively shallow depth, large surface area and high shoreline complexity are likely to yield higher biodiversity values in benthic invertebrate communities. The preference of many invertebrate taxa for certain vegetation or bottom substrate types (Minshall, 1984) may also influence the biodiversity. Many studies have shown positive relationships between taxa richness, habitat heterogeneity and area for many invertebrate orders (Huston, 1994; Rosenzweig, 1995; Heino, 2000; Céréghino et al., 2008). Therefore, many authors consider that increasing habitat heterogeneity is the most efficient strategy to recover biodiversity (Tockner et al., 1999; Tews et al., 2004; Gallardo et al., 2012). Wetland morphological differentiation and water quality were probably the most relevant factors that could explain the different community structure among the sites we monitored. A diversified macrophyte community and/or the availability of other habitats can support more specialized taxa such as Odonata, Hemiptera and Trichoptera, that in this study appeared more frequently in natural ponds and in the artificial pools that were built by the Park management with a high vegetation complexity. Water quality also plays a role: constructed wetlands, characterized by the highest nutrient concentrations, showed assemblages composed mainly by pioneer taxa and tolerant families of Diptera, Coleoptera and Ephemeroptera, the latter including only individuals belonging to the Baetidae family.

Although water quality improvement is generally the primary objective of treatment wetlands, the creation of habitats is a complementary outcome of these projects (Knight et al., 2001; Hsu et al., 2011). Macroinvertebrates are often early colonists of new created wetlands, with abundance and diversity approaching high levels within a few years from wetland construction (Hansson et al., 2005; Batzer et al., 2006; Stewart and Downing, 2008).
The two constructed wetlands in this study were recently built (Spring 2008) and monitored during their first year of working. Gallardo et al. (2012) found significant differences in biodiversity between natural and recently constructed wetlands. We found differences in the composition of macroinvertebrate assemblages, but in this study the overall level of biodiversity was comparable among the three ecosystem categories. Some authors have found similar taxa richness in natural wetlands and in 1 to 10 year-old constructed wetlands (Barnes, 1983; Stanczak and Keiper, 2004; Hansson et al., 2005; Spieles et al., 2006), but critics often argue that certain aspects of created wetlands (e.g., plant communities and soils) can not be similar to natural wetlands for at least almost 5 years (Campbell et al., 2002). Miguel-Chinchilla et al. (2014) have recently demonstrated that environmental factors better explain the pond biodiversity than pond age, influencing the number and type of taxa that are able to colonize man-made ponds. However, the creation of constructed wetlands has the potential to provide a habitat that may be unavailable within the surrounding landscape (Becerra-Jurado et al., 2009). Thus, a more integrated management of water quality and biodiversity enhancement, as suggested by the integrated constructed wetlands concept (Harrington and Ryder, 2002; Harrington et al., 2005; Scholz et al. 2007), is required.

The constructed wetlands we examined showed the potential, right from the start of their insertion in the environment, to be valuable elements in the local ecological network. The pioneer invertebrate communities let them reach an overall biodiversity level similar to the other ponds in the park within a year. This finding, apparently, confirms our starting hypothesis that macroinvertebrate assemblages in constructed wetlands that share comparable physical habitats with natural wetlands can have similar biodiversity levels. Nevertheless, it will be necessary to assess if the new artificial and constructed wetlands could support a comparable community composition in the long term. Ruhí et al. (2013) demonstrated that pioneer assemblages in man-made ecosystems $\left(1^{\text {st }}\right.$ year after construction) present a structure that is highly nested within the natural ones at a regional scale, due to the arrival of active dispersers from nearby water bodies. A progressive decrease in the populations of active colonizers, and the progressive erratic arrival of passive dispersers, make nestedness value fall over time in man-made wetlands, allowing diversity values higher at mid term $\left(3^{\text {rd }}\right.$ year) than in the early successional stages. At the same time, the differences in macroinvertebrate community composition that we detected between natural and constructed wetlands suggest that invertebrate assemblages in wetlands with various origin can differentiate in functionality, thus creating the premises for significant ecosystem divergences. 


\section{CONCLUSIONS}

Constructed wetlands and artificial ponds show the potential, right from the start of their insertion in the environment, to be valuable elements in the local ecological network, because they achieve, in the short term, invertebrate biodiversity levels comparable to those of natural wetlands. Artificial ecosystems such as constructed wetlands mitigate the local aquatic habitat loss and can be considered effective not only for wastewater treatment but also in restoration projects.

Habitat heterogeneity is the most relevant factor that influences taxa richness. Independently from the wetland origin, the higher the availability of different habitats, the higher the taxa richness. This aspect could and should be taken into account in the design of constructed wetland in order to enhance their positive environmental impacts by forcing their role as biodiversity pools. Water quality also influences the macroinvertebrate community structure. Despite the comparable overall biodiversity level, constructed wetlands with higher pollutant concentrations show different assemblage compositions, and this can lead to divergences in ecosystem functionality at long term.

\section{ACKNOWLEDGMENTS}

The authors are grateful to the Regional Park Parco Pineta di Appiano Gentile e Tradate for funding and supporting the research, and to its staff for the help on field.

\section{REFERENCES}

APHA, 1998. Standard methods for the examination of water and wastewater, $20^{\text {th }}$ ed. American Public Health Association, Washington DC, USA.

Balcombe CK, Anderson JT, Fortney RH, Kordek WS, 2005. Aquatic macroinvertebrate assemblages in mitigated and natural wetlands. Hydrobiologia 541:175-188.

Barnes LE, 1983. The colonization of ball-clay ponds by macroinvertebrates and macrophytes. Freshwater Biol. 13:561-578.

Batzer DP, Cooper R, Wissinger SA, 2006. Wetland animal ecology, p. 242-284. In: D.P. Batzer and R.R. Sharitz (eds.), Ecology of freshwater and estuarine wetlands. University of California Press, Berkeley, CA, USA.

Becerra-Jurado G, Callanan M, Gioria M, Baars J-R, Harrington R, Kelly-Quinn M, 2009. Comparison of macroinvertebrate community structure and driving environmental factors in natural and wastewater treatment ponds. Hydrobiologia 634:153-165.

Boix D, Gascón S, Sala J, Badosa A, Brucet S, López-Flores R, Martinoy M, Gifre J, Quintana XD, 2008. Patterns of composition and species richness of crustaceans and aquatic insects along environmental gradients in Mediterranean water bodies. Hydrobiologia 597:53-69.

Brady VJ, Cardinale BJ, Gathman JP, Burton TM, 2002. Does facilitation of faunal recruitment benefit ecosystem restoration? An experimental study of invertebrate assemblages in wetland mesocosms. Restor. Ecol. 10:617-626.
Brodersen KP, Dall PC, Lindegaard C, 1998. The fauna in the upper stony littoral of Danish lakes: macroinvertebrate as trophic indicators. Freshwater Biol. 39:577-592.

Campbell DA, Cole CA, Brooks RP, 2002. A comparison of created and natural wetlands in Pennsylvania, USA. Wetl. Ecol. Manag. 10:41-49.

Céréghino R, Ruggiero A, Marty P, Angélibert S, 2008. Biodiversity and distribution patterns of freshwater invertebrates in farm ponds of a southwestern French agricultural landscape. Hydrobiologia 597:43-51.

Della Bella V, Bazzanti M, Chiarotti F, 2005. Macroinvertebrate diversity and conservation status of Meditarranean ponds in Italy: water permanence and mesohabitat influence. Aquat. Conserv. 15:538-600.

EPA, 2002. Methods of evaluating wetland condition: introduction to wetland biological assessment. EPA-822-R-02-014. U.S. Environmental Protection Agency, Office of Water, Washington DC, USA.

Fairchild GW, Faulds AM, Matta JF, 2000. Beetle assemblages in ponds: effects of habitat and site age. Freshwater Biol. 44:523-534.

Friday LE, 1987. The diversity of macroinvertebrate and macrophyte communities in ponds. Freshwater Biol. 18:87-104.

Gallardo B, Cabezas A, Gonzalez E, Comín FA, 2012. Effectiveness of a newly created oxbow lake to mitigate habitat loss and increase biodiversity in a regulated floodplain. Restor. Ecol. 20:387-394.

Gascón S, Boix D, Sala J, Quintana XD, 2008. Relation between macroinvertebrate life strategies and habitat traits in Mediterranean salt marsh ponds (Empordà wetlands, NE Iberian Peninsula). Hydrobiologia 597:71-83.

Hansson LA, Brönmark C, Nilsson PA, Ábjörnsson K, 2005. Conflicting demands on wetland ecosystem services: nutrient, retention, biodiversity, or both? Freshwater Biol. 50: 705-714.

Harrington R, Dunne EJ, Carroll P, Keohane J, Ryder C, 2005. The concept, design and performance of integrated constructed wetlands for the treatment of farmyard dirty water, p. 179-188. In: E.J. Dunne, K.R. Reddy and O.T. Carton (eds.), Nutrient management in agricultural watersheds: a wetlands solution. Wageningen Academic Publishers.

Harrington R, Ryder C, 2002. The use of integrated constructed wetlands in the management of farmyard runoff and waste water. In: Proceedings Nat. Hydrology Seminar on Water Resources Management Sustainable Supply and Demand, Tullamore, Ireland.

Heino J, 2000. Lentic macroinvertebrate assemblage structure along gradients in spatial heterogeneity, habitat size and water chemistry. Hydrobiologia 418:229-242.

Herrmann J, Boström A, Bohman I, 2000. Invertebrate colonization into the man-made Kalmar Dämme wetland dam system. Int. Ver. The. 27:1653-1656.

Hsu CB, Hsieh HL, Yang L, Wu SH, Chang JS, Hsiao SC, Su $\mathrm{HC}$, Yeh CH, Ho YS, Lin HJ, 2011. Biodiversity of constructed wetlands for wastewater treatment. Ecol. Eng. 37:1533-1545.

Huston ML, 1994. Biological diversity. The coexistence of species on changing landscapes. Cambridge University Press: $681 \mathrm{pp}$.

Knight RL, Clark RA Jr., Bastian RK. 2001. Surface flow (SF) 
treatment wetlands as habitat for wildlife and humans. Water Sci. Technol. 44:27-37.

Martínez-Sanz C, Fernández-Aláez C, García-Criado F, 2012. Richness of littoral macroinvertebrate communities in mountain ponds from NW Spain: what factors does it depend on? J. Limnol. 71:154-163.

Miguel-Chinchilla L, Boix D, Gascón S, Comín FA, 2014. Macroinvertebrate biodiversity patterns during primary succession in manmade ponds in north-eastern Spain. J. Limnol. 73:428-440.

Minshall GW, 1984. Aquatic insect-substratum relationships, p. 358-400. In: V.H. Resh and D.M. Rosenberg (eds.), The ecology of aquatic insects. Praeger Publishing.

Mitsch WJ, Wu X, Nairn RW, Weihe PE, Wang N, Deal R, Boucher CE,1 998. Creating and restorating wetlands: a whole-ecosystem experiment in self-design. Bioscience 48:1019-30.

Moreno-Mateos D, Power ME, Comín FA, Yockteng R, 2012. Structural and functional loss in restored wetland ecosystem. Plos Biology 10: e1001247.

Oertli B, 1995. Spatial and temporal distribution of the zoobenthos community in a woodland pond (Switzerland). Hydrobiologia 300-301:195-204.

Oertli B, Biggs J, Céréghino R, Grillas P, Joly P, Lachavanne $\mathrm{JB}, 2005$. Conservation and monitoring of pond biodiversity: introduction. Aquat. Conserv. 15:535-540.

Oksanen J, Blanchet FG, Kindt R, Legendre P, Minchin PR, O'Hara RB, Simpson GL, Solymos P, Stevens MHH, Wagner $H, 2013$. Vegan: community ecology package. R package ver. 2.0-10. Available from: http://CRAN.R-project.org/package $=$ vegan

Palmer M, Allan JD, Meyer J, Bernhardt ES, 2007. River restoration in the twenty-first century: data and experiential future efforts. Restor. Ecol. 15:472-481.

Palmer MA, Menninger HL, Bernhardt E, 2010. River restoration, habitat heterogeneity and biodiversity: a failure of theory or practice? Freshwat. Biol. 55:205-222.

R Core Team, 2013. R: A Language and Environment for Statistical Computing. R Foundation Statistical Computing.

Rasmussen JB, 1988. Littoral zoobenthic biomass in lakes, and its relationship to physical, chemical and trophic factors. Can. J. Fish. Aquat. Sci. 45:1436-1447.

Rosenzweig MJ, 1995. Species diversity in space and time. Cambridge University Press: 436 pp.

Ruhí A, Boix D, Sala J, Gascón S, Quintana XD, 2009. Spatial and temporal patterns of pioneer macrofauna in recently created ponds: taxonomic and functional approaches. Hydrobiologia 634:137-151.

Ruhí A, Boix D, Gascón S, Sala J, Quintana XD, 2013. Nested- ness and successional trajectories of macroinvertebrate assemblages in man-made wetlands. Oecologia 171:545-556.

Scatolini SR, Zedler JB, 1996. Epibenthic invertebrates of natural and constructed marshes of San Diego Bay. Wetlands 16:24-37.

Sharitz RR, Batzer DP, 1999. An introduction to freshwater wetlands in North America and their invertebrate, p. 1-24. In: D.P. Batzer, B.R. Russell and S.A. Wissinger (eds.), Invertebrates in freshwater wetlands of North America: ecology and management. J. Wiley \& Sons.

Scholz M, Harrington R, Carroll P, Mustafa A, 2007. The integrated constructed wetlands (ICW) concept. Wetlands 27:337-354.

Spieles DJ, Coneybeer M, Horn J, 2006. Community structure and quality after 10 years in two central Ohio mitigation bank wetlands. Environ. Manage. 38:837-852.

Spieles DJ, Mitsch W, 2000. Macroinvertebrate community structure in high- and low- nutrient constructed wetlands. Wetlands 20:716-729.

Stanczak M, Keiper JB, 2004. Benthic invertebrates in adjacent created and natural wetlands in northeastern Ohio, USA. Wetlands 20:212-218.

Stewart TW, Downing JA, 2008. Macroinvertebrate communities and environmental conditions in recently constructed wetlands. Wetlands 28:141-150.

ter Braak CJF, Smilauer P, 1998. CANOCO reference manual and user's guide to Canoco for Windows: Software for canonical community ordination, ver. 4.5. Centre for Biometry, Wageningen.

Tews J, Brose U, Grimm V, Tielborger K, Wichmann MC, Schwager M, Jeltsch F, 2004. Animal species diversity driven by habitat heterogeneity/diversity: the importance of keystone structures. J. Biogeogr. 31:79-92.

Tockner K, Schiemer F, Baumgartner C, Kum G, Weigand E, Zweimuller I, Ward JV, 1999. The Danube restoration project: species diversity patterns across connectivity gradients in the floodplain system. Regul. River 15:245-258.

Tolonen KT, Hämäläinen H, Holopainen IJ, Karjalainen J, 2001. Influence of habitat type and environmental variables on littoral macroinvertebrate communities in a large lake system. Arch. Hydrobiol. 152:1808-1822.

Weatherhead MA, James MR, 2001. Distribution of macroinvertebrates in relation to physical and biological variables in the littoral zone of nine New Zealand lakes. Hydrobiologia 462:115-129.

Zedler JB, 2006. Wetland restoration, p. 348-406. In: D.P. Batzer and R.R. Sharitz (eds.), Ecology of freshwater and estuarine wetlands. University of California Press. 